\title{
Chemical characterization of landfill leachate and its impact on the receiving natural water-body surrounding the Naboro Landfill, Suva, Fiji Island
}

\author{
Francis S. Mani, Esha D. Chetty, and Matakite Maata \\ School of Biological and Chemical Sciences, Faculty of Science, Technology and Environment \\ University of the South Pacific, Laucala Campus, Suva, Fiji \\ mani_f@usp.ac.fj
}

\section{Extended Abstract}

Municipal Solid Waste (MSW) management is one of the most important environmental issues in the Pacific Island countries and landfilling waste is one of the most preferred disposal methods. However landfills generate highly contaminated wastewater called leachate. In Fiji Islands there is only one anaerobic landfill, the Noboro landfill, which commenced its operation in 2005 just few kilometers away from the capital city. It is properly lined and has a leachate collection system, which diverts all the leachate produced into a settling tank (stage 1) and then the leachate flows into three aeration ponds (stage 2). After the residence in aeration ponds the leachate is further treated in a natural wetland (stage 3 ) and then it outflows into a natural creek (mixing zone or stage 4) in the vicinity of the landfill.

Leachate samples were collected on a monthly basis from the different stages of the treatment and also water samples from further upstream and downstream of the mixing zone were also collected to investigate the impact of landfill leachate on the surrounding natural water-body. The parameters that were monitored are $\mathrm{pH}$, conductivity, heavy metals, DO, BOD, COD, ammonia, nitrate, nitrite and phosphates. From stage 1 to stage 4 , the following $\%$ decrease in concentrations and the average concentration at stage 4 were observed: 46 - $99 \%$ decrease in ammonia levels with an average value of $25.9 \mathrm{mg} / \mathrm{L}$; 49 - 90\% decrease in phosphate levels with an average value of $6.1 \mathrm{mg} / \mathrm{L} ; 29-92 \%$ decrease in nitrite levels with an average value of $9.6 \mathrm{mg} / \mathrm{L} ;-43-90 \%$ decrease in nitrate levels with an average value of $12.4 \mathrm{mg} / \mathrm{L}$. It is very clear that aeration ponds and the natural wetland treatment removes nutrients in the leachate efficiently before it is discharged into the natural waters. Only ammonia and nitrate are above the maximum landfill leachate discharge standards established by Fiji, which is $10 \mathrm{mg} / \mathrm{L}$. A maximum of $40 \%$ removal of COD was achieved in the current treatment of leachate samples and this demonstrate that the treatment employed is not very efficient in the removal on non-biodegradable organic compounds from the leachate and an additional treatment options needs to be implemented in future to increase the COD removal efficiency. The levels of heavy metals found in the leachate were very low but above the USEPA discharge limit. The low levels of heavy metals in the leachate samples were attributed to high $\mathrm{pH}$ or very alkaline conditions which could precipitate heavy metals in the settling tank.

The levels of pollutants monitored further upstream and downstream of the mixing zone does not show any significant differences in physico-chemical properties measured. It can be concluded that the landfill leachate treatment method used at the Naboro landfill, particularly at high $\mathrm{pH}$ due to addition of lime sludge in the landfill, is very effective in removing nutrients and heavy metals. 